\title{
KARAKTERISASI PRODUK BIOMASSA SELULER DALAM BIOREAKTOR MEMBRAN PADA BIODEGRADASI ZAT WARNA AZO REMAZOL BLACK 5
}

\author{
Puti Sri Komala*), Yommi Dewilda, Mohamad Zulfan, dan Zilvia Wulandari \\ Jurusan Teknik Lingkungan, Fakultas Teknik, Universitas Andalas \\ Kampus Limau Manis, Padang, Telp. (0751)72497, Fax. (0751)72564 \\ ${ }^{*}$ Penulis korespondensi: putisrikomala@ft.unand.ac.id
}

\begin{abstract}
CHARACTERIZATION OF CELLULAR BIOMASS PRODUCTS IN MEMBRANE BIOREACTOR IN AZO DYE REMAZOL BLACK 5 BIODEGRADATION.In this study the characterization of cellular biomass products in anoxic-oxic membrane bioreactor $(M B R)$ in azo dye Remazol Black 5(RB 5) biodegradation in the low solid retention time (SRT) was evaluated. The MBR consists of anoxic-, contact-, and stabilization tank and was equipped with an external polysulfone membrane which placed between the contact and the stabilization tanks. Feed was the mixture of azo dye $R B$ with a concentration of $120 \mathrm{mg} / \mathrm{L}$ and co-substrate tempe industrial wastewater with COD ranging between 2,080-2,400 $\mathrm{mg} / \mathrm{L}$. With a combination of filtration and backwash time of 1 hour and 1 minute, the MBR was operated for 50 days with an average flux 9 lmh and pressures of 0.8 to 2 bars. The cellular components of each tank were measured as extracellular polymeric material (EPS) and soluble microbial products (SMP). The color removal efficiency was in the range of 66-77\%, while COD removal efficiency i.e. 44-50\%. Unfavorable biomass transfer between tanks may decrease the organics removal of MBR, neverthelessthis transfer does not affect the EPS. The carbohydrates content of the SMP and EPS from each tank was higher than that of the the protein content. Carbohydrates coming from the hydrolysis productsseem the main cause of the fouling compared to the proteins. The high concentration of the EPS was in the stabilization tank due to the poor oxygen transfer within the biofilm structure while passing through the membrane.
\end{abstract}

Keywords: anoxic-oxic membrane bioreactor (MBR);azo dye Remazol Black 5; extracellular polymeric substance (EPS); soluble microbial products (SMP); solid retention time (SRT)

\begin{abstract}
Abstrak
Dalam penelitian ini karakterisasi produk biomassa seluler dalam bioreaktor membran (BRM) anoksik-oksik dalam biodegradasi zat warna Azo Remazol Black 5 (RB 5) pada umur lumpur rendah (SRT) telah dievaluasi. BRM terdiri dari tangki anoksik, kontak, dan stabilisasi serta membran eksternal polysulfone yang diletakkan diantara tangki kontak dan stabilisasi. Umpan yang digunakan adalah campuran zat warna RB 5 dengan konsentrasi $120 \mathrm{mg} / \mathrm{L}$ dan $\mathrm{ko}$-substrat limbah tempe dengan COD berkisar antara 2.080-2.400 mg/L. Dengan kombinasi waktu filtrasi dan backwash 1 jam dan 1 menit, BRM dapat beroperasi selama hampir 50 hari dengan fluks rata-rata 9 lmj dan tekanan 0,8-2 bar. Komponen seluler masing-masing tangki diukur sebagai material polimer ekstraseluler (EPS) dan produk mikrobial terlarut (SMP). Efisiensi penyisihan warna pada berkisar antara 66-77\%, sedangkan penyisihan COD berkisar pada 44-50\%. Perpindahan biomassa antar tangki yang tidak sempurna diperkirakan telah menurunkan kinerja penyisihan senyawa organik BRM, namun perpindahan ini tidak berpengaruh terhadap EPS. Kandungan karbohidrat pada SMP maupun EPS masing-masing tangki nilainya lebih tinggi dibandingkan dengan kadar protein. Karbohidrat yang berasal dari produk-produk hidrolisis merupakan penyebab utama fouling dibandingkan protein. Konsentrasi EPS yang tinggi terdapat pada tangki stabilisasi akibat transfer oksigen yang buruk dalam struktur biofilm saat melewati membran.
\end{abstract}

Kata kunci:Bioreaktor Membran (BRM) anoksik-oksik; zat warna azo Remazol Black 5; material polimer ekstraseluler (EPS); produk mikrobial terlarut (SMP); umur lumpur (SRT) 
How to Cite This Article: Komala, P.S., Dewilda, Y., Zulfan, M., dan Wulandari, Z., (2015), Karakterisasi Produk Biomassa Seluler dalam Bioreaktor Membran pada Biodegradasi Zat Warna Azo Remazol Black 5, Reaktor, 15(3), 139-147, http://dx.doi.org/ 10.14710/reaktor.15.3.139-147

\section{PENDAHULUAN}

Industri tekstil merupakan salah satu industri yang mengkonsumsi air dalam jumlah yang relatif tinggi di dalam prosesnya, sementara air limbah yang dihasilkan mengakibatkan pencemaran warna yang persistent dan bersifat toksik meskipun konsentrasi yang rendah. Tanpa pengolahan, zat warna akan tetap di lingkungan untuk perioda yang sangat lama. Pengolahan biologi merupakan salah satu alternatif pengolahan warna yang sering digunakan selain pengolahan fisika-kimia, karena disamping ramah lingkungan dan kemampuannya untuk memineralisasi warna (Pandey dkk., 2007; Parshetti dkk., 2006). Diantara berbagai proses-proses biologi, bioreaktor membran (BRM) merupakan pengolahan yang potensial dalam pengolahan warna karena kemampuannya beroperasi pada umur lumpur (SRT) yang tinggi. Pengolahan biologi dengan umur lumpur yang tinggi diketahui dapat mengolah senyawa toksik atau yang sulit diuraikan (Sipma, 2010). Teknologi membran dengan ukuran pori submikron diharapkan dapat menahan hampir seluruh biomassa termasuk bakteri dan virus pada permukaan membran mendukung operasi BRM pada umur lumpur panjang (Stephenson dkk., 2000). Namun, permasalahan umum yang sering dijumpai pada proses bioreaktor membran adalah terjadinya fouling akibat penyumbatan pada permukaan dan pori membran. Foulingpada membran sebagian besar disebabkan oleh material polimer ekstraseluler (EPS) yaitu senyawa pembentuk agregat mikroba seperti biofilm, flok dan cairan lumpur aktif (Judd, 2006). Mikroorganisme dalam flok lumpur aktif berada dalam matriks kompleks yang terdiri protein, polisakarida, lemak dan asam nukleat, yang disebut sebagai EPS flok (Menniti dkk, 2009). EPS menurut Menniti berperan penting dalam pembentukan flok lumpur aktif dan memberikan stabilitas pada flok dalam lingkungan turbulensi tinggi. Ekstraksi EPS atau disebut juga produk mikroba terlarut (SMP) merupakan komponen sel terlarut yang dilepaskan selama lisis sel dan mempunyai pengaruh besar terhadap permeabilitas membran. Menniti juga melaporkan, bahwa sebagian besar komponen organik dalam pengolahan air limbah secara biologi merupakan komponen EPS terlarut dibandingkan dengan substrat awal. EPS terlarut dianggap sebagai penyebab utama foulant dalam sistem BRM (Chang dkk., 2002; Le-Clech dkk., 2006).

Sejauh ini aerasi merupakan metoda yang paling umum yang sering digunakan untuk meminimasi fouling, sehubungan dengan kemampuannya untuk menghasilkan tegangan geser pada permukaan membran (Le-Clech dkk., 2006). Aerasi yang diberikan melalui pompa mempunyai pengaruh shear stress terhadap sel-sel mikroorganisme yang dipaparkan, akibatnya matriks EPS yang membungkus sel-sel tersebut akandilepaskan ke dalam medium (Kim dkk., 2001). Turbulensi pompa dapat menginduksi pecahnya flok mikroba dan menghasilkan banyak partikel koloid halus dan EPS yang dilepaskan berpengaruh besar terhadap hambatan membran.

Penelitian untuk pengolahan zat warna azo RB5 telah dilakukan oleh Komala (2008) menggunakan bioreaktor membran anoksik-oksik yang terdiri dari modifikasi proses lumpur aktif kontak-stabilisasi yang dikombinasikan dengan membran ultrafiltrasi eksternal. Reaktor anoksik digunakan di awal proses berperan untuk proses pemotongan gugus azo oleh mikroorganisme aerob yang terlebih dahulu diaerasi dan distabilisasi pada proses kontak-stabilisasi, sedangkan membran ultrafiltrasi secara eksternal digunakan untuk menggantikan proses sedimentasi pada proses lumpur aktif konvensional.

Untuk meminimalisasi fouling, pada penelitian Komala berikutnya (2011) dilakukan kombinasi waktu filtrasi-pencucian 3 jam-1 menit sampai 1 jam-1 menit serta pemberian aerasi pada umpan sebesar 0,7-1 bar. Adanya aerasi pada membran dapat mendukung pertumbuhan mikroorganisme yang melekat pada membran dengan suplai oksigen untuk mendegradasi ko-substrat, sehingga kinerja BRM meningkat. Pemberian aerasi pada umpan membran disertai dengan pengaturan waktu filtrasi dan backwash dapat menghasilkan fluks stabil dan waktu retensi hidrolis (HRT) yang diharapkan, dibanding tanpa aerasi pada umpan membran. Dari hasil optimasi parameter biologi diperoleh HRT tangki anoksik, kontak dan stabilisasi optimum adalah 4, 2, dan 4 jam (Komala, 2012).

Dalam penelitian ini akan dikaji lebih jauh kinerja BRM anoksik-oksik terhadap penyisihan zat warna azo dan senyawa organik pada umur lumpur rendah pada kondisi BRM optimum. Selain itu akan dievaluasi lebih jauh pengaruh umur lumpur tersebut terhadap kinerja membran serta mekanisme fouling yang terjadi melalui produk ekstraseluler mikroba EPS dan SMP pada masing-masing tangki dalam bioreaktor membran.

\section{METODE PENELITIAN \\ Mikroorganisme}

Mikroorganisme yang digunakan adalah mikroorganisme tercampur yang berasal dari lumpur aktif BRM pada penelitian Komala (2012). Mikroorganisme ini berasal dari campuran mikroorganisme unit pengolahan lumpur aktif instalasi pengolahan air buangan industri tekstil PT Daliatex Bandung dan pengolahan industri zat warna Dystar Cilegon.Mikroorganisme ini kemudian dibiakkan 
menggunakan campuran ko-substrat limbah tempe dan zat warna sebagai umpan dalam reaktor batch dengan volume $5 \mathrm{~L}$ dan diaerasi secara aerob. Pembubuhan $\mathrm{NaOH}$ diberikan pada larutan sampai diperoleh $\mathrm{pH}$ yang netral. Hasil biakan mikroorganisme dimasukkan ke dalam BRM untuk percobaan selanjutnya.

\section{Ko-substrat dan Zat Warna}

Ko-substrat limbah tempe yang digunakan sebagai sumber organik, bersifat asam dengan $\mathrm{pH}$ antara 4-5, yang berasal dari air limbah hasil perebusan tempe. Karakteristik air limbah tempe yang diperoleh dari penelitian sebelumnya (Komala dkk, 2013) dapat dilihat pada Tabel 1. Kandungan organik air limbah tempe adalah 5,880 $\mathrm{mg}$ COD/L dan 1,865 mgBOD/L, lebih tinggi dibandingkan dengan COD 4 $\mathrm{g} / \mathrm{L}$ yeast extract, yaitu 3,167 mg /L (Komala, 2011).

Tabel 1. Karakteristik air limbah industri tempe

\begin{tabular}{cc}
\hline Parameter & Konsentrasi $[\mathrm{mg} / \mathrm{L}]$ \\
\hline $\mathrm{COD}$ & 5.880 \\
$\mathrm{BOD}$ & 1.865 \\
$\mathrm{NO}_{3}$ & 219,69 \\
$\mathrm{NO}_{2}$ & 2,15 \\
$\mathrm{NH}_{4}$ & 453 \\
$\mathrm{TKN}^{-}$ & 690 \\
$\mathrm{Cl}^{-}$ & 74,3 \\
$\mathrm{PO}_{4}{ }^{-3}$ & 587 \\
$\mathrm{SO}_{4}^{-2}$ & 115,78 \\
$\mathrm{Al}$ & 7,93 \\
$\mathrm{Ca}$ & 9,28 \\
$\mathrm{Fe}$ & 10,47 \\
$\mathrm{~K}$ & 12,76 \\
$\mathrm{Mg}$ & 8,81 \\
$\mathrm{Na}$ & 10,96 \\
\hline
\end{tabular}

Sumber : Komala dkk. (2013)

Pada percobaan batch sebelumnya diperoleh ko-substrat limbah tempe optimum berkisar antara 8\%-10\% v/v limbah industri tempe terhadap larutan substrat total (Komala, 2010). Zat warna yang digunakan adalah zat warna azo reaktif Remazol Black-5dengan konsentrasi $120 \mathrm{mg} / \mathrm{L}$. Panjang gelombang diukur dengan Spectrophotometer Shimadzu UV-2600. Panjang gelombang optimum zat warna azo Remazol Black 5 diperoleh pada $600 \mathrm{~nm}$. Nilai puncak panjang gelombang ini masih berada pada rentang 595-609 nm seperti yang diperoleh pada beberapa penelitian sebelumnya (You dkk., 2010; Komala, 2011; Wulandari, 2013).

\section{Bioreaktor Membran Anoksik-oksik}

Instalasi bioreaktor membran anoksik-oksik (Gambar 1) yang digunakan dalam penelitian ini berasal dari penelitan sebelumnya (Komala dkk., 2011). Pada penelitian ini membran yang digunakan adalah jenis ultrafiltrasi hollow fiber GDP filter yang terbuat dari bahan PS (poly sulfone) dengan diameter Fiber ID/OD 0,8 mm/2,1 mm, panjang membran 495 $\mathrm{mm}$, luas membran $0,24 \mathrm{~m}^{2}$. Prosedur operasional mengacu kepada penelitian Komala dkk. (2011).

Umpan dialirkan melalui pompa dengan laju aliran $1 \mathrm{~L} / \mathrm{jam}$ ke dalam tangki anoksik yang dilengkapi mixer dengan putaran $40 \mathrm{rpm}$ untuk mengaduk larutan. Dari tangki anoksik larutan biomassa kemudian secara gravitasi dialirkan ke dalam tangki kontak dan diaerasi. Larutan kemudian dipompakan ke membran eksternal menggunakan pompa diafragma dengan laju alir $1 \mathrm{~L} / \mathrm{jam}$ dan tekanan operasi antara 0,8-2 bar, menghasilkan permeate sebagai hasil penyaringan dan retentate berupa konsentrasi biomassa yang kemudian masuk ke dalam tangki stabilisasi. Aliran dalam membran dilakukan secara crossflow dan secara periodik dilakukan pencucian dengan air bersih berlawanan arah aliran normal dari sel ke lumen membran. Interval pencucian dikontrol dengan pengatur waktu dan katup solenoid dengan perbandingan waktu 1 jam filtrasi dan 1 menit backwash.

Biomassa dari tangki stabilisasi selanjutnya diresirkulasikan ke tangki anoksik dan bercampur kembali dengan umpan yang masuk. Waktu retensi hidrolis (HRT) tangki anoksik, kontak dan stabilisasi dijaga konstan yaitu 4, 2, dan 4 jam. Secara periodik fluks diukur dengan menghitung waktu yang diperlukan untuk mendapatkan volume tertentu. Konsentrasi warna umpan, bak anoksik, kontak, stabilisasi dan permeate membran diamati setiap hari, setelah kondisi tunak konsentrasi MLVSS, warna, dan COD di setiap reaktor diukur berdasarkan APHA (1995).

\section{Umur Lumpur (SRT)}

Umur lumpur dihitung dari perbandingan jumlah biomassa dalam bioreaktor dengan jumlah biomassa yang meninggalkan bioreaktor (persamaan 1). Pembuangan lumpur dapat dilakukan di tangki stabilisasi, namun jika kadar lumpur di permeate cukup tinggi, maka pembuangan lumpur di tangki stabilisasi dilakukan dengan memperhitungkan kadar lumpur di permeate.

Dimana:

$$
\theta_{c}=\frac{\left(X_{a n} \cdot V_{a n}\right)+\left(X_{k} \cdot V_{k}\right)+\left(X_{s} \cdot V_{s}\right)}{\left(q_{w} \cdot X_{S}\right)+(Q-q w) X e}
$$

$\mathrm{Q}=$ Debit yang masuk (L/hari)

$\mathrm{X}_{\mathrm{k}}=$ Konsentrasi biomassa di tangki kontak (mg/L)

$\mathrm{V}_{\mathrm{k}}=$ Volume tangki kontak (L)

$\mathrm{X}_{\mathrm{s}}=$ Konsentrasi biomassa di tangki stabilisasi (mg/L)

$\mathrm{V}_{\mathrm{s}}=$ Volume tangki stabilisasi (L)

$\mathrm{X}_{\mathrm{e}}=$ Konsentrasi biomassa di permeate $(\mathrm{mg} / \mathrm{L})$

$\mathrm{q}_{\mathrm{w}}=$ Debit lumpur yang dibuang (L/hari) 


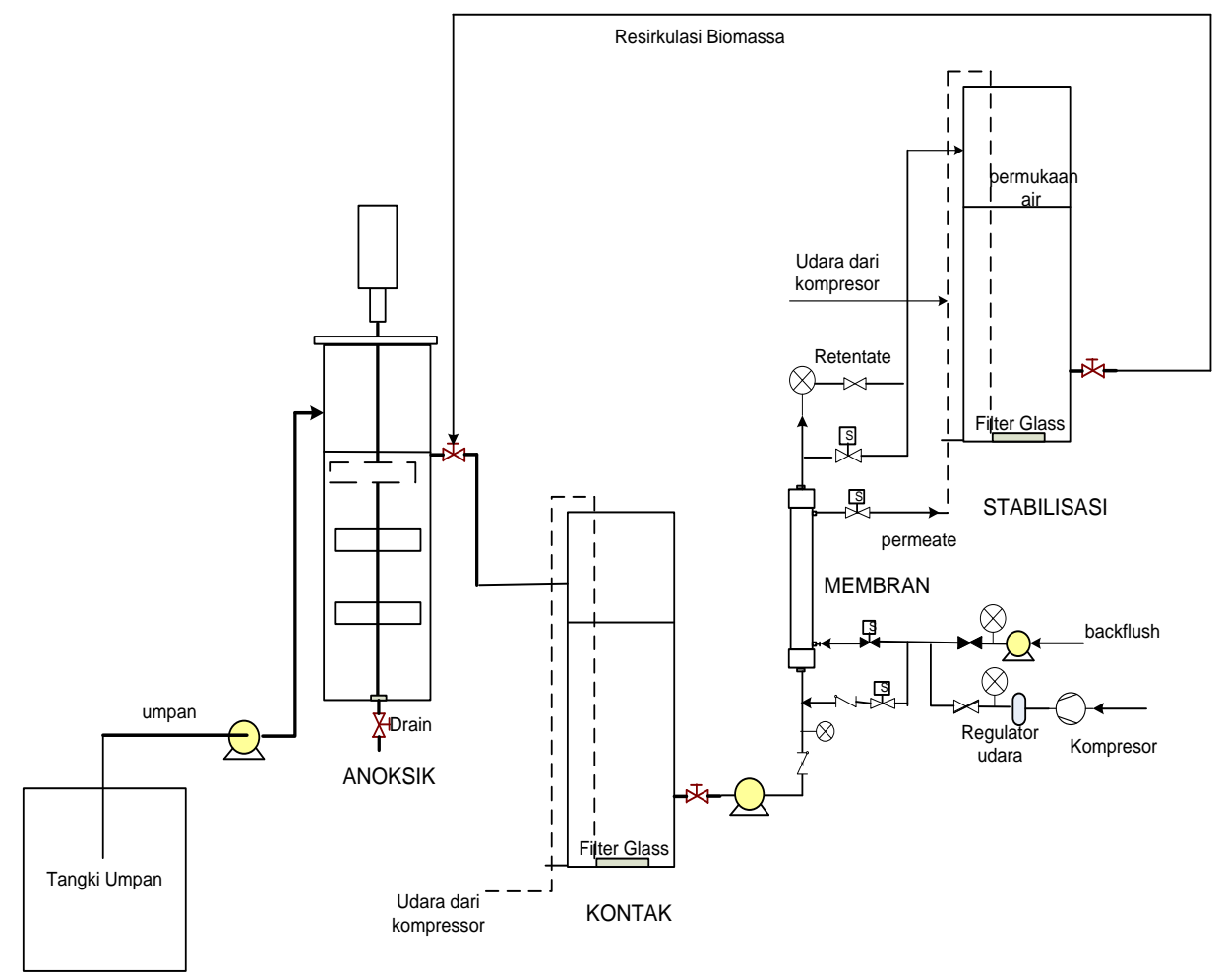

Gambar 1. Skema bioreaktor membran anoksik-oksik (Komala dkk.,2011)

\section{Permeabilitas Membran}

Permeabilitas membran adalah perbandingan nilai fluks terhadap tekanan, seperti yang dapat dilihat pada persamaan 2 .

$$
P=\frac{J}{T M P}
$$

Dimana:

$\mathrm{P}=$ permeabilitas $\left[\mathrm{L} / \mathrm{m}^{2}\right.$.jam.bar $]$

$\mathrm{J}=$ fluks permeasi $\left[\mathrm{L} / \mathrm{m}^{2}\right.$.jam $]$ atau $\mathrm{LMJ}$

TMP = tekanan lintas membran[bar]atau[Pa]

Permeabilitas awal membran menggunakan air murni (aquades) dilakukan pada berbagai tekanan operasi BRM (0,2-0,8 bar). Peralatan yang digunakan untuk mengukur permeabilitas membran adalah pompa diafragma debit $0,4 \mathrm{~L} /$ menit, membran ultrafiltrasi dengan luas $=0,24 \mathrm{~m}^{2}$, pressure gauge, stopwatch dan gelas ukur. Aquades dipompakan ke dalam membran selama 5 menit melalui bagian input. Waktu diukur dengan menggunakan stopwatch, tekanan diatur pada 0,2 bar. Permeat yang keluar ditampung selama waktu tersebut dan volume yang tertampung diukur dengan menggunakan gelas ukur. Prosedur yang sama dilakukan untuk tekanan 0,4 bar, 0,6 bar, 0,8 bar.

\section{Pengukuran EPS dan SMP}

Perubahan kandungan material polimer ekstraseluler protein dan karbohidrat dari filtrat (SMP) dan sludge (EPSc dan EPSp) lumpur aktif pada masing-masing reaktor diukur. Prosedur pengukuran EPS dan SMP dilakukan dengan metoda pemanasan (Le-Clech dkk., 2006). Sampel berupa larutan tersuspensi yang berasal dari reaktor-reaktor tangki umpan, anoksik, kontak, permeate dan stabilisasi diambil sebanyak $50 \mathrm{ml}$, lalu disentrifugasi selama 5 menit pada 5000 g. Supernatant hasil sentrifugasi disaring menggunakan kertas saring 1,2 $\mu \mathrm{m}$. Supernatant saring diukur kandungan protein dan karbohidratnya sebagai SMPp dan SMPc. Filtrat hasil sentrifugasi diberi air deionisasi sampai volume seperti sampel awal, kemudian diaduk selama 10 menit dan dipanaskan selama 10 menit dengan suhu $80^{\circ} \mathrm{C}$ dan disentrifugasi $7000 \mathrm{~g}$ selama 10 menit. Supernatant hasil sentrifugasi disaring menggunakan kertas saring 1,2 $\mu \mathrm{m}$, Supernatant saring diukur kandungan protein dan karbohidratnya sebagai EPSp (protein) dan EPSc (karbohidrat).

SMPp dan EPSp (protein) diukur dengan metode Lowry, sedangkan SMPc dan EPSc (karbohidrat) diukur dengan prinsip Dubois menggunakan Metode Fenol-Sulfat (Le-Clech dkk., 2006).

\section{HASIL DAN PEMBAHASAN}

\section{Permeabilitas Membran}

Dari hasil percobaan uji permeabilitas membran awal dengan menggunakan aquadest pada tekanan operasi membran 0,2-0,8 bar menghasilkan fluks yang berkisar antara 1,4-11,75 lmj. Semakin meningkatnya tekanan operasi, nilai fluks semakin meningkat akan tetapi tidak demikian halnya dengan nilai permeabilitas. Permeabilitas membran yang diperoleh melalui regresi pengukuran fluks air bersih terhadap tekanan antara $0,2-0,8$ bar merupakan nilai slope yaitu 14,7 lmj/bar (Gambar 3). 


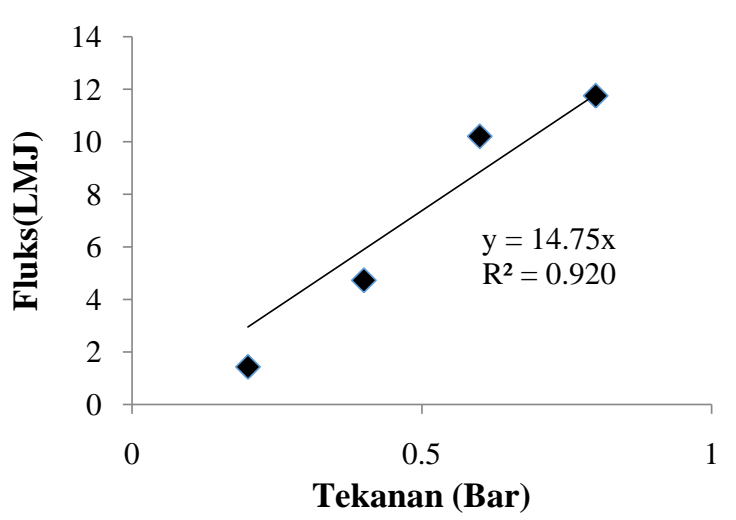

Gambar 3. Permeabilitas membran

Nilai permeabilitas yang diperoleh relatif rendah bila dibandingkan dengan nilai permeabilitas membran ultrafiltrasi. Menurut Mulder (1996) nilai permeabilitas untuk membran ultrafiltrasi berada pada kisaran 50-500 lmj/bar. Rendahnya nilai permeabilitas yang diperoleh disebabkan karena tekanan operasi BRM yang digunakan relatif kecil dibandingkan tekanan operasi membran ultrafiltrasi yang umum digunakan yaitu 1,5-2,5 bar (Mulder, 1996).

\section{Penyisihan Warna dan COD pada Bioreaktor Membran Anoksik-oksik}

Hasil pengukuran efisiensi penyisihan warna pada SRT 2 dan 5 hari dapat dilihat pada Gambar 4, sedangkan jumlah biomassa sebagai VSS dalam masing-masing bioreaktor pada umur lumpur tersebut diperlihatkan pada Tabel 2.

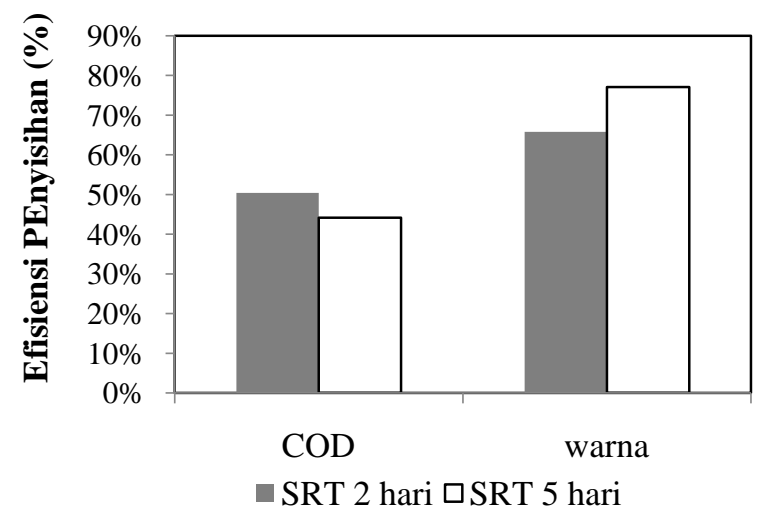

Gambar 4. Efisiensi penyisihan warna dan COD pada SRT 2 dan 5 Hari

Tabel 2. Konsentrasi biomassa dalam reaktor pada SRT 2 dan 5 hari

\begin{tabular}{cccc}
\hline \multirow{2}{*}{$\begin{array}{c}\text { SRT } \\
\text { (hari) }\end{array}$} & \multicolumn{3}{c}{ VSS (mg/hari) } \\
\cline { 2 - 4 } & Tangki Anoksik & $\begin{array}{c}\text { Tangki } \\
\text { Kontak }\end{array}$ & $\begin{array}{c}\text { Tangki } \\
\text { Stabilisasi }\end{array}$ \\
\hline 2 & 369 & 440 & 526 \\
5 & 2083 & 1562 & 2409 \\
\hline
\end{tabular}

Efisiensi penyisihan warna pada grafik diatas diperoleh dari selisih konsentrasi warna pada tangki inlet dan permeat. Terlihat bahwa efisiensi penyisihan warna pada bioreaktor membran anoksik-oksik pada kondisi SRT 2 hari yaitu 66\%, sedangkan pada SRT 5 hari lebih tinggi yaitu $77 \%$. Sebaliknya penyisihan COD pada SRT 2 hari sedikit lebih tinggi dibandingkan SRT 5 hari yaitu 50\% terhadap $44 \%$.

Peningkatan umur lumpur dari 2 hari menjadi 5 hari telah meningkatkan jumlah biomassa keseluruhan dalam reaktor. Peningkatan ini juga mengakibatkan mikroorganisme yang berperan untuk mendegradasi warna khususnya di tangki anoksik semakin bertambah, sehingga meningkatkan efisiensi penyisihan warna. Komala (2011) mengungkapkan mikroorganisme di tangki anoksik merupakan mikroorganisme yang paling berperan dalam pemutusan warna. Kondisi yang bertolakbelakang terjadi pada penyisihan senyawa organik, meningkatnya umur lumpur telah menurunkan penyisihan senyawa organik. Meskipun konsentrasi biomassa meningkat di keseluruhan bioreaktor, namun terjadi penurunan biomassa di tangki kontak yang masuk dari tangki anoksik. Komala melaporkan bahwa mikroorganisme yang hidup di tangki kontak adalah mikroorganisme dominan yang melakukan penyisihan senyawa organik. Jumlah mikroorganisme yang berkurang diperkirakan telah menurunkan kinerja BRM keseluruhan dalam menyisihkan senyawa organik.

Hasil yang diperoleh dalam penelitian ini sedikit berbeda dengan hasil yang diperoleh Lorenco dkk. (2001). Diungkapkan bahwa, peningkatan SRT dari 10 hari menjadi 15 hari pada zat warna Remazol Briliant Violet 5R pada konsentrasi $100 \mathrm{mg} / \mathrm{L}$ dapat meningkatkan penyisihan warna maupun penyisihan COD, namun ketika digunakan zat warna Remazol Black B saat SRT 15 dan 20 hari pada sistem yang sama penyisihan warna tetap rendah, tidak terjadi peningkatan penyisihan. Diperkirakan bahwa struktur Remazol Black B yang lebih kompleks menyebabkan tingkat penyisihan warna yang lebih rendah jika dibandingkan dengan Remazol Briliant Violet 5R. Hal yang sama diperoleh oleh Kapdan dan Ozturk(2005) bahwa kenaikan SRT dari 12 hari menjadi 15 dapat meningkatkan penyisihan COD dan dekolorisasi Remazol Red RR, namun peningkatan SRT dari 15 hari menjadi 30 hari tidak terdapat peningkatan penyisihan COD. Jika dibandingkan penelitian tersebut, hasil penelitian yang dilakukan saat ini masih berada pada rentang SRT rendah, sehingga kinerja penyisihan warna maupun COD masih belum optimal. Perpindahan biomassa yang tidak sempurna dari tangki anoksik ke tangki kontak serta dari membran ke tangki stabilisasi turut menurunkan kinerja penyisihan senyawa organik yang diperoleh.

\section{Kinerja Membran}

BRM anoksik-oksik dapat beroperasi selama 44 hari dengan fluks rata-rata $11 \mathrm{lmj}$ dan tekanan berkisar antara 0,8-2 bar (Gambar 5). Pada hari ke 14 sd 19, 24-25 dan 41 terjadi permasalahan dalam pompa membran dan umpan, sehingga operasi 
dihentikan. Selama penghentian BRM tersebut aerasi pada masing-masing tangki tetap dijalankan untuk menjaga biomassa tetap hidup. Dari nilai tersebut diperoleh permeabilitas rata-rata 7,36 lmj/bar.

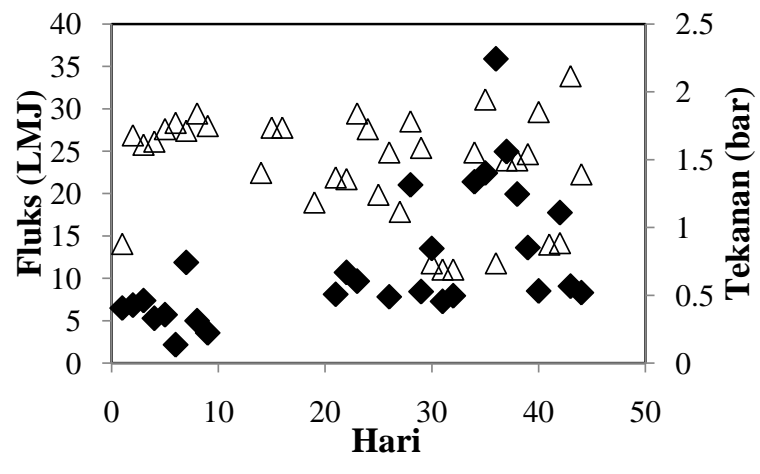

• Fluks (LMJ) $\triangle$ Tekanan (bar)

Gambar 5. Kinerja membran selama 44 hari operasi

Permeabilitas membran mengalami penurunan dari semula 18,2 lmj/bar akibat interaksi membran dengan biomassa. Relatif stabilnya nilai permeabilitas yang diperoleh disebabkan oleh adanya aplikasi sistem autobacwash setiap jam dengan durasi 1 menit selama pengoperasian membran. Hal ini dapat dilihat sampai 40 hari beroperasi nilai fluks masih cukup stabil meskipun tekanan mulai naik di atas 2 bar. Fluks membran dioperasikan pada fluks konstan agar debit yang masuk dan keluar dari BRM sama dan HRT pada masing reaktor dapat dijaga stabil. Pada hari-hari terakhir nilai fluks meningkat di atas 20 LMJ dan tekanan 2,1 bar. BRM yang beroperasi pada fluks konstan dan rendah disertai dengan tekanan membran konstan dapat mereduksi fouling melalui reduksi gaya konvektif terhadap membran (Le-Clech dkk., 2006), sehingga BRM dapat beroperasi dalam jangka panjang. Laju fluks yang diperoleh dari penelitian ini berada di bawah rentang BRM terendam menurut Stephenson (2000) yaitu 20-200 Lmj/bar, namun masih berada pada rentang spesifik fluks membran sidestream UF yang beroperasi pada 1-2 bar dan kecepatan crossflow 1,5 m/detik yaitu $90 \mathrm{Lmj} / \mathrm{bar}$, dan setelah 80 hari beroperasi turun menjadi $15 \mathrm{Lmj} /$ bar.

\section{SMP dan EPS}

Limbah tempe yang digunakan sebagai kosubstrat pada BRM anoksik-oksik ini memiliki kandungan senyawa organik dan nutrien yang tinggi bahkan jika dibandingkan dengan yeast extract. Namun di pihak lain komponen ini merupakan penyebab fouling pada membran. Le-Clech dkk.(2006) menyatakan bahwa mekanisme fouling akibat material terlarut dan koloid diperkirakan lebih berperan dalam penyumbatan pori membran, sedangkan padatan tersuspensi berkontribusi terutama pada resistensi/hambatan lapisan cake. Pada Gambar 6 dan 7 dapat dilihat kandungan SMP dan EPS pada masingmasing reaktor pada umur lumpur 2 hari. Kandungan karbohidrat pada masing-masing tangki memiliki nilai yang lebih tinggi jika dibandingkan dengan kadar protein baik pada parameter SMP maupun EPS. Sementara itu, total SMP (protein dan karbohidrat) pada tangki-tangki aerob yaitu tangki kontak dan stabilisasi nilainya lebih tinggi dibandingkan dengan tangki anoksik. Komponen SMP yang tinggi ini merupakan produk dari hidrolisis substrat dan lisis sel baik akibat biomassa yang mati dan akibat turbulensi aerasi. Hal ini juga ditegaskan oleh Judd (2006) bahwa nilai SMP pada proses aerob lebih tinggi dibandingkan dengan SMP pada kondisi anaerob. Nielsen dkk. (1997) juga melaporkan, bahwa komponen mikroba terlarut atau SMP dilepaskan ke dalam larutan akibat produk lisis sel, produk hidrolisis dari degradasi substrat influen serta erosi akibat turbulensi permukaan.

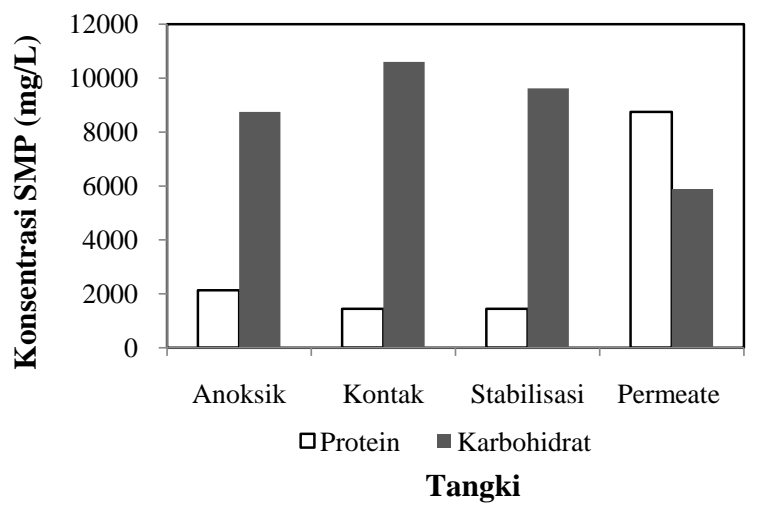

Gambar 6. Kandungan SMP protein dan karbohidrat dalam reaktor

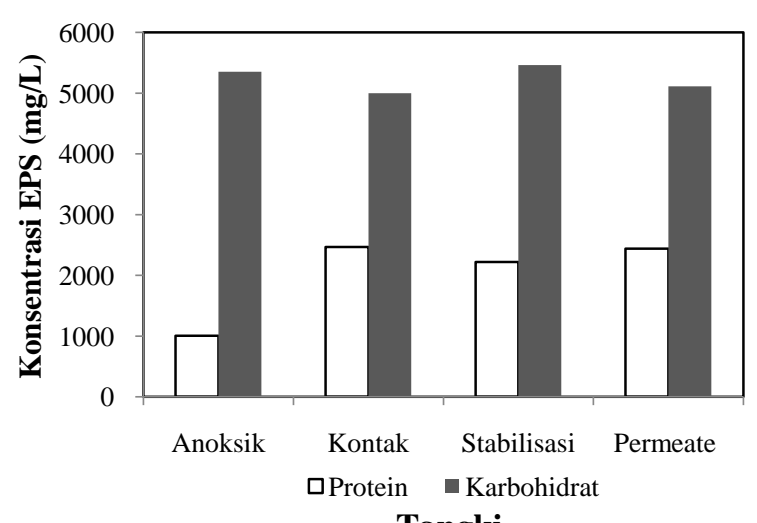

Tangki

Gambar 7. Kandungan EPS protein dan karbohidrat dalam reaktor

Jika dilihat dari penyisihan senyawa organik sebagai COD, konsentrasi senyawa organik telah mengalami penurunan sekitar $44-50 \%$ akibat dari proses degradasi mikroorganisme dan membentuk produk hidrolisis yang bergabung dengan produk lisis sel mikroba. Produk mikroba yang paling tinggi dalam bioreaktor adalah karbohidrat, komponen koloid karbohidrat baik dalam SMP maupun EPS inilah yang diperkirakan merupakan komponen dominan dalam membran fouling. Sejalan dengan yang dilaporkan oleh Drews dkk. (2006a) bahwa fraksi koloid 
polisakarida menunjukkan potensi fouling yang lebih tinggi.

Konsentrasi protein SMP yang meningkat pada permeate setelah melewati membran menunjukkan bahwa terdapat kandungan protein biomassa yang dilepaskan ke dalam larutan setelah melewati membran. Dibandingkan pada tangki-tangki sebelumnya kandungan protein pada kisaran 2.000 $\mathrm{mg} / \mathrm{L}$, sedangkan pada permeate nilainya meningkat tajam hampir mencapai $9.000 \mathrm{mg} / \mathrm{L}$. Konsentrasi protein SMP yang diukur berasal dari suspensi lumpur yang terbawa dalam permeat, yang memperlihatkan banyaknya protein yang terikat pada biomassa tersuspensi dan tertahan ketika berada di membran kemudian terbawa aliran melalui permeate. Hal ini juga ditegaskan oleh Drews dkk. (2006b), bahwa fraksi yang dianalisa sebagai protein juga mengandung komponen humus yang biasanya dapat melewati membran.

Oleh karena itu, kandungan protein yang ada dalam permeate juga mewakili kandungan protein yang tertahan di membran. Kandungan SMP protein pada permeate jauh lebih tinggi dibandingkan protein dalam umpan yaitu $1.635 \mathrm{mg} / \mathrm{L}$, diperkirakan akumulasi protein yang tertahan pada membran semakin meningkat dengan berjalannya waktu operasi bioreaktor. Nilai SMP yang tinggi juga berkaitan dengan waktu tinggal biomassa (HRT) di seluruh tangki yaitu 10 jam, yang mengakibatkan kematian biomassa meningkat dan berkontribusi terhadap pembentukan koloid dan material terlarut.

Menurut Judd (2006) protein lebih bersifat hidrofobik, sedangkan karbohidrat lebih bersifat hidrofilik terhadap membran. Akibatnya protein lebih banyak dilepaskan ke larutan dibandingkan dengan karbohidrat, yang kemudian terbawa ke aliran permeate, sedangkan sebagian karbohidrat tertahan pada membran. Karbohidrat yang berikatan dengan membran tersebut diperkirakan merupakan penyebab fouling pada membran. Judd (2006) juga menegaskan pada SRT yang rendah senyawa polisakarida SMP berperan utama terhadap fouling.

Umpan yang terdiri dari campuran zat warna dan limbah tempe memiliki kandungan karbohidrat yang lebih tinggi dibandingkan dengan protein. Berbeda dengan komposisi limbah tempe pada penelitian sebelumnya (Komala, 2011), dimana kandungan protein limbah tempe lebih besar dari karbohidrat. Komposisi umpan pada kedua penelitian memperlihatkan kecenderungan yang sama terhadap komposisi SMP di reaktor-reaktor. Pada umpan dengan komposisi protein yang tinggi, maka komposisi protein pada reaktor-reaktor pun memiliki komposisi SMP protein yang tinggi juga, demikian juga pada umpan yang memiliki karbohidrat yang tinggi komposisi karbohidrat di reaktor-reaktornya juga menunjukkan kandungan karbohidrat yang tinggi. Meskipun demikian, kecenderungan yang sama terjadi pada permeat, dimana kandungan SMP protein di kedua penelitian lebih tinggi dibandingkan kandungan karbohidratnya meskipun komposisi umpan berbeda.

Seperti komposisi karbohidrat dan protein dalam umpan, setelah masuk ke dalam tangki-tangki dalam BRM anoksik-oksik pola komposisi kedua material tersebut dalam EPS tidak berubah. Jumlah total karbohidrat dan protein dan komposisinya dalam EPS di ketiga tangki terlihat tidak berubah signifikan, memperlihatkan tidak terjadi kerusakan pada biomassa setelah perpindahan dari masing-masing tangki. Konsentrasi EPS karbohidrat pada tangki stabilisasi yaitu $5.469 \mathrm{mg} / \mathrm{L}$ sedikit mengalami peningkatan setelah melalui membran dari semula $4.999 \mathrm{mg} / \mathrm{L}$ pada tangki kontak. Terjadinya zona anaerobik pada lapisan fouling pada membran menyebabkan terjadinya peluruhan endogenous, sehingga kondisi ini mengakibatkan peningkatan konsentrasi karbohidrat. Bakteri-bakteri yang ada pada BRM merupakan kombinasi bakteri aerob dan fakultatif anaerob, adanya transisi antara kondisi aerobik dan anaerobik menyebabkan stress pada bakteri bahkan dapat menyebabkan lisis sel, sehingga dihasilkan konsentrasi protein dan karbohidrat yang nilainya cukup tinggi pada tangki stabilisasi.

Fenomena lainnya dapat terlihat pada nilai EPS protein pada tangki-tangki aerob yaitu tangki kontak dan stabilisasi lebih tinggi dibandingkan EPS protein tangki anoksik, dan EPS karbohidrat tangki stabilisasi lebih tinggi dibandingkan dengan tangki anoksik. Namun EPS karbohidrat tangki anoksik masih lebih tinggi dibandingkan tangki kontak. Aerasi yang dilakukan lebih panjang pada tangki stabilisasi dapat meningkatkan kandungan protein maupun karbohidrat pada lumpur, jika dibandingkan dengan flok yang tanpa adanya aerasi pada tangki anoksik. Yun dkk (2006) menyatakan bahwa jumlah polisakarida yang diekstraksi dari biofilm aerob lebih tinggi jika dibandingkan dengan biofilm anoksik, menunjukkan struktur flok aerob lebih kuat jika dibandingkan dengan anaerob. Pengukuran kandungan SMP dan EPS pada membran dengan cara pembedahan membran diperlukan pada penelitian selanjutnya, untuk mengetahui secara jelas perubahan komposisi protein dan karbohidrat ketika berada pada membran.

\section{KESIMPULAN}

Bioreaktor membran (BRM) aerob-anoksik telah dioperasikan untuk biodegradasi zat warna azo Remazol Black 5 selama hampir 50 hari menggunakan ko-substrat air limbah industri tempe serta umur lumpur rendah. BRM beroperasi pada fluks rata-rata 9 lmj dan tekanan 0,8-2 bar dengan mengaplikasikan sistem autobackwash setiap jam filtrasi dengan durasi 1 menit dan menghasilkan penyisihan warna berkisar pada $66-77 \%$, sedangkan penyisihan COD pada kisaran 44-50\%.Jumlah EPS total di seluruh tangki dalam BRM tidak mengalami perubahan signifikan, hal ini memperlihatkan tidak terjadi kerusakan pada biomassa setelah perpindahan dari masing-masing 
tangki maupun akibat turbulensi pompa.Kandungan karbohidrat SMP dan EPS pada seluruh tangki memiliki nilai yang lebih tinggi dibandingkan dengan kadar protein, diperkirakan karbohidrat sebagai penyebab fouling pada membran.

Konsentrasi EPS tertinggi terdapat pada tangki stabilisasi akibat transfer oksigen yang buruk dalam struktur biofilm saat melewati membran.Komposisi protein dan karbohidrat dalam umpan mempengaruhi komposisi SMP pada masing-masing tangki BRM, namun tidak mempengaruhi komposisi SMP pada permeate, dimana kandungan protein permeate lebih tinggi dibandingkan karbohidrat akibat akumulasi protein pada membran yang terbawa pada aliran.

\section{UCAPAN TERIMAKASIH}

Penelitian ini didanai melalui Dana Penelitian Hibah Bersaing DIPA Universitas Andalas Nomor: Dipa-023.4.2.415061/ 2013.

\section{DAFTAR PUSTAKA}

American Public Health Association, (1995), Standard Methods for the Examination of Water and Wastewater, A.D. Eaton, L.S. Clesceri, A.E. Greenberg, (Eds.), 19th ed., Washington D.C.

Chang, I.S., Clech, P.L., Jefferson, B., and Judd, S., (2002), Membrane fouling in membrane bioreactors for wastewater treatment, Journal of Environmental Engineering, 128, pp. 1018-1029.

Drews, A., Lee, C.H., and Kraume, M., (2006a), Membrane fouling - a review on the role of EPS, Desalination, 200, pp.186-188.

Drews, A., Vocks, M., Iversen, V., Lesjean, B., and Kraume, M., (2006b), Influence of unsteady membrane bioreactor operation on EPS formation and filtration resistance, Desalination, pp. 192, pp. 1-9.

Judd, S., (2006), The MBR book: Principles and Applications of Membrane Bioreactors in Water and Wastewater treatment, Elsevier,

Kapdan, I.K.andOzturk, R., (2005), Effect of operating parameters on color and COD removal performance of SBR: Sludge age and initial dyestuff concentration, Journal of Hazardous Materials, B123, pp. 217-222.

Kim, J.S., Lee, C.H., and Chang, I.S., (2001), Effect of pump shear on the performance of a crossflow membrane bioreactor, Water Research, 35 (9), pp. 2137-2144.

Komala, P.S., Effendi, AJ, Wenten, IG, dan Wisjnuprapto, (2008), Pengaruh waktu retensi hidrolis reaktor anoksik terhadap biodegradasi zat warna azo reaktif menggunakan bioreaktor membran aerobanoksik, Jurnal Teknologi Lingkungan, 4, 91, Jurusan Teknik Lingkungan-Universitas Trisakti.
Komala, P.S., Effendi, A.J., Wenten, IG., dan Wisjnuprapto, (2010), Perbandingan Ko-substrat Optimum pada Sistem Batch dan Bioreaktor Membran Anoksik-oksik Kontinu dalam Biodegradasi Zat Warna Azo,Prosiding Seminar Teknik Kimia Soehadi Reksowardojo, Teknik Kimia ITB Bandung.

Komala, P.S., Effendi, A.J., Wenten, IG., and Wisjnuprapto, (2011), Performance of anoxic-oxic membrane bioreactor for Azo dye biodegradation, International Journal of Civil \& Environmental Engineering, 11,pp. 29-36.

Komala, P.S., Effendi, A.J., Wenten, IG., and Wisjnuprapto, (2012), Performance changes of aerobic-anoxic membrane bioreactor for Azo dye biodegradation under different hydraulic retention time in Anoxic tank, Prosiding International Conference on Construction Industry, Facilities and Assets Management, pp. 277-282.

Komala, P.S., Dewilda, Y., and Wulandari, Z., (2013), Biodegradation of azo dye remazol black 5 by mono culture bacteria with tempe industrial wastewater as co-substrate,International Journal of Technology, vol 4, Issue 3, pp. 240-248, ISSN 2086-9614.

Le-Clech, P., Chen, V., and Fane, A.G., (2006), Fouling in membrane bioreactors used in wastewater treatment, Journal of Membrane Science, 284, pp. 1753.

Lorenço, N.D., Novais, J.M., and Pinheiro, H.M., (2001), Effect of Some Operational Parameters on Textile Dye Biodegradation in a Sequential Batch Reactor, Journal of Biotechnology, 89, pp. 163-174.

Menniti, A., Kang, S., Elimelech, M., and Morgenrotha, E., (2009), Influence of shear on the production of extracellular polymeric substances in membrane bioreactors, Water Research, 43, pp. 43054315.

Mulder, M.,(1996), Basic Principles of Membrane Technology, Kluwer Academic Publisher.

Nielsen, P.H., Jahn, A., and Palmgren, R., (1997), Conceptual model for production and composition of exopolymers in biofilms, Water Science and Technology, 36 (1), pp. 11-19.

Pandey, A., Singh, P., and Iyengar, L., (2007), Review Bacterial decolorization and degradation of azo dyes, International Biodeterioration \& Biodegradation, pp. 59-73.

Parshetti, G., Kalme, S., Saratale, G., and Govindwar, S., (2006), Biodegradation of Malachite Green by Kocuria rosea MTCC 1532, Acta Chimica Slovenica, 53, 492-498.

Sipma, J., Osuna, B., Collado, N., Monclús, H., Ferrero, G., Comas, J., andRodriguez-Roda, I., (2010), Comparison of removal of pharmaceuticals in MBR 
and activated sludgesystem. Desalination,250, pp. 653-659.

Stephenson, T., Judd, S., Jefferson, B., and Brindle, K., (2000), Membrane Bioreactors for Wastewater Treatment, IWA Publishing Company. UK.

Wulandari, Z.,(2013), Biodegradasi Zat Warna Azo Remazol Black 5 Menggunakan Limbah Tempe Sebagai Ko-Substrat Oleh Bakteri Kultur Murni dan Pengaruhnya Terhadap Penyisihan Senyawa Organik. Tugas Akhir S-1 Teknik Lingkungan, Universitas Andalas. Padang.
You, S.J., Damodar, R.A., and Hou, S.C., (2010), Degradation of Reactive Black 5 dye using anaerobic/aerobic membrane bioreactor (MBR) and photochemical membrane reactor, Journal of Hazardous Materials, 177, pp. 1112-1118.

Yun, M., Yeon, K., Park, J., Lee, C., Chun, J.,and Lim, D., (2006), Characterization of biofilm structure and its effect on membrane permeability in MBR for dye wastewater treatment, Water Research, 40, pp. 4552 . 